\title{
ASSESSMENT OF THE IMPULSE CHARACTERISTICS OF SOLID- PROPELLANT DETONATION ROCKET ENGINES
}

\author{
Institute of Technical Mechanics \\ of the National Academy of Sciences of Ukraine and the State Space Agency of Ukraine \\ 15 Leshko-Popel St., Dnipro 49005, Ukraine; e-mail: vako@email.ua
}

The aim of this paper is to compare calculated impulse characteristics of solid-propellant detonation rocket engines with test results. The paper describes the principle of operation and the design of impulse rocket engines that use an explosive as solid propellant. Calculated estimates of the impulse characteristics of solidpropellant detonation rocket engines (SPDREs) with a cord explosive charge are presented. Parameters of energy conversion in the combustion chambers of SPDREs in conditions of their possible use are considered. The isoentropic exponent of combustion product expansion is calculated for shock processes. Calculated combustion product exhaust velocities and relative specific impulses for various explosives are presented. The calculations were made for a wide variety of explosives. All the calculated results are original. SPDREs were tested on specially made earth-banked benches. The test engines differed in dimensions, detonating cord placement in different combustion chambers, and nozzle shape and dimensions. The engines had detonating cords of different types and dimensions. A model nose cone separation and removal system with a solidpropellant detonation engine was tested. The SPDRE test methods are described. The calculated results agree with the firing test results obtained on the testing ground of the Institute of Technical Mechanics of the National Academy of Sciences of Ukraine and the State Space Agency of Ukraine. The SPDRE energy characteristics calculated and verified by experiment may be used in the design of systems for rocket nose cone separation and removal in the dense atmosphere and in the design of explosive pushers, which are employed for the same purposes and use the same explosives.

Keyuords cord explosive charge, combustion chamber, specific impulse, temperature, explosive.

1. Rozlovsky A. I. Scientific Fundamentals of Explosion Safety Engineering for Combustible Gases and Vapors. Moscow: Khimiya, 1972. 364 pp. (in Russian).

2. Kutuzov B. N. Boulder Blasting Moscow: Nedra, 1980. 392 pp. (in Russian).

3. Abramovich G. N. Applied Gas Dynamics. Moscow: Fizmatgiz, 1969. 824 pp. (in Russian).

4. Guliy N. A., Kovalenko N. D., Tynyna S. V. Gas-jet propulsion system with a pulse-fed receiver. Teh. Meh. 2002. No. 2. Pp. 64-70. (in Russian).

5. Efremov E. I., Vovk A. A. Boudler Blasting Handbook. Kiev: Naukova Dumka, 1983. P. 59. (in Russian).

6. Timnath I. Rocket Engines on Chemical Fuel. Moscow: Mir, 1990. 292 pp. (in Russian).

7. Kovalenko N. D., Kukushkin V. I., Yhnatev A. D., Kirichenko A. O. Scientific and technical basis for the development of solid-propellant detonation rocket engines. Kosmicheskaya Tekhnika. Raketnoye Vooruzheniye. 2016. No. 1. Pp. 34-45. (in Russian).

8. USSR Inventor's Certificate No. 27354. Method and bench for solid-propellant detonation rocket engine firing tests. Voitenko A. B., Golovach A. G., Golubenko N. S., Kovalenko N. D., Onishchenko A. T.; applicant: Institute of Technical Mechanics, application No. 3143488/40-23, filed on May 15, 1986. (in Russian). 